\title{
A 5-year study of the impact of peatland revegetation upon DOC concentrations
}

\author{
S.M. Qassim ${ }^{\text {a }}$, S.D. Dixon ${ }^{\text {a }}$, J.G. Rowson ${ }^{\text {b }}$, F. Worrall ${ }^{\mathrm{a},},{ }^{*}$ M.G. Evans ${ }^{c}$, A. Bonn ${ }^{d}$ \\ aDept. of Earth Sciences, Science Laboratories, South Road, Durham DH1 3LE, UK \\ bDepartment of Geography and Geology, Edge Hill University, Omskirk L394QP, UK \\ cUpland Environments Research Unit, School of Environment, Education \& Development, University of Manchester, Oxford Road, Manchester M139PL, UK \\ dBerlin-Brandenburg Institute of Advanced Biodiversity Research (BBIB), Freie Universität Berlin, Institute of Biology, Königin-Luise-Str. 1-3, 14195 Berlin, Germany \\ * Corresponding author. Tel.: +44 (0)191334 2295; fax: +44 (0)1913342301. \\ E-mail address: Fred.Worrall@durham.ac.uk (F. Worrall).
}

\begin{abstract}
Summary
Peatlands are among the largest long-term soil carbon stores on the globe, but their degradation can lead to significant carbon losses. Therefore, restoration of peatlands has received considerable attention but the impact of revegetation upon critical water quality parameters has not been assessed. In this paper we consider a 5-year study of three restored sites in comparison to both an unrestored, bare peat control and to a vegetated control that did not require restoration. The soil porewater dissolved organic carbon concentration (DOC) was measured (6 replicates) for each restoration treatment and each control. The soil water measurements were made in the context of measuring the depth to water table; soil water $\mathrm{pH}$ and conductivity; and DOC concentration in surface runoff for the same restored and control treatment. The studyshowed that the average soil porewater DOC concentration on the restored sites rose significantly over the 5 year study representing a 34\% increase relative to the vegetated control and an $11 \%$ increase relative to the unrestored, bare control. Soil pore water concentrations were not significantly different from surface runoff DOC concentrations, and therefore restoration as conducted by this study would have contributed to water quality deterioration in the catchment. However, had water table restoration been conducted alongside revegetation then a significant decline in DOC concentrations could have been realised.
\end{abstract}

Keywords: Peatland, Restoration, DOC

1. Introduction

Peatlands are a key carbon store and an important water source for many countries (Holden et al., 2007). These environments are in many areas being degraded by a number of processes including: commercial extraction (e.g. Soini et al., 2010); atmospheric deposition of pollutants (e.g. Bragazza et al., 2006); forestry and drainage (e.g. Joosten, 2009; Martikainen et al., 1995); grazing and agriculture (e.g. Vasander et al., 2003); and fire (e.g. van der Werf et al., 2010). These processes and other land management systems have not always been conducive to carbon storage or to increased water quality (Holden et al., 2007). Of particular concern has been the dissolved organic carbon (DOC) concentration in runoff from peat-covered catchments. Aquatic carbon fluxes can account for $30-50 \%$ of net primary productivity (e.g. Nilsson et al., 2008). Incomplete removal of DOC leads to coloured water which is of low aesthetic quality; it increases the potential for biological contamination by consuming free residual chlorine; and can form potentially carcinogenic tri-halomethanes (Condie et al., 1983; Volk et al., 2002) whose concentration in drinking water is limited by law in the UK (Hsu et al., 2001). The principal cause of concern with regard to $\mathrm{DOC}$ and water treatment has been the sustained increases in DOC concentration observed for many catchments across the northern hemisphere (Monteith et al., 2007). Studies by Mitchell et al. (2008), Wallage and Holden (2010) and Worrall et al. (2011) discuss plausible mechanisms by which land management practices could contribute to the documented rise in DOC concentrations, including: changes in soil pH; or the amount and nature of water flow brought about by land management. Land management or degradation can more readily be reversed than external drivers such as increases in air temperature, and therefore land management or degradation represents an opportunity to improve water quality in the runoff from peat-covered catchments.

The impact of land management upon DOC concentrations in runoff has been investigated for a number of land management practises on peatlands, including: prescribed burning (Clay et al., 2009a); drainage (Gibson et al., 2009); drain-blocking (Peacock 
et al., 2013); afforestation (Jandl et al., 2007); and grazing (Ward et al., 2007). Land management (e.g. drainage); degradation due internal (e.g. trampling); and external pressures (e.g. climate change) can result in the development of bare soil areas and so restoration in these areas has focused upon revegetation (Reed et al., 2009). Studies of revegetated peat soils report on many of the components of a peat soil carbon budget. It is not surprising that studies on re-vegetation universally report increased carbon uptake via gross primary productivity (GPP) (e.g. Marinier et al., 2004), and with increasing GPP increased root respiration would be expected to lead to increased net ecosystem respiration (NER - e.g. Trinder et al., 2008); increased root exudation (Freeman et al., 2004); stimulating enzymatic decomposition (Shackle et al., 1999), but still leading to improved net ecosystem exchange (NEE - Dixon et al., 2014). For methane the authors know of no studies reporting declines in methane flux upon revegetation with most reporting an increase (e.g. Kivimaki et al., 2008) and others reporting no significant change (Keller et al., 2005). However, re-vegetation does lower the particulate organic carbon flux (POC, e.g. Evans et al., 2006). The authors know of no studies of the dissolved $\mathrm{CO}_{2}$ budget of re-vegetated areas. Worrall et al. (2011) showed that the carbon sequestration benefit of peatland restoration via revegetation would range between 122 and 833 tonnes $\mathrm{C} / \mathrm{km}^{2} / \mathrm{yr}$.

Dissolved organic carbon is a key component of water quality in upland catchments, however, the consequences of revegetation on $\mathrm{DOC}$ concentrations are unclear. Authors that have investigated $\mathrm{DOC}$ concentrations in revegetated peatlands report a range of behaviour: two report an increase (Trinder et al., 2008; Waddington et al., 2008); and two report a decline (Mackay and Tallis, 1995; Strack and Zuback, 2013). Gough et al. (2012) have found differences between in soil water DOC concentrations and composition between different vegetation types on organic soils (including peats) but could not consider revegetation of bare soil. It is therefore possible to hypothesize that by changing water tables and through increased litter production, or root exudation, that revegetation could lead to net increases or net decreases in DOC concentration in peat-covered catchments. Therefore, the aim of this study was to assess the impact of long term revegetation of bare peat soils on the concentration of DOC within and exported from those soils.

\section{Approach and methodology}

\subsection{Study site}

All study sites were selected from across the Bleaklow Plateau in the Peak District National Park (UK national grid ref. SK094961 -N53:27:43 W1:51:33 - Fig. 1). The plateau is an area of extensive deep peat with altitudes between 468 and $630 \mathrm{~m}$ above sea level, annual average rainfall of $1200 \mathrm{~mm}$, and the range of average monthly air temperatures between 0.6 and 12.4 _C, with August the warmest and February the coldest months on average (Worrall et al., 2011). Between September 2006 and April 2012, on average, the wettest month was October $(118.9 \mathrm{~mm})$, the lowest average monthly rainfall was in February $(57.1 \mathrm{~mm})$. The area has been subject to heavy grazing, visitor pressure, wildfires and has a legacy of atmospheric deposition of metals and acids; these factors along with others have led to the extensive gully erosion and dissection of the peat bogs on the plateau (Evans et al., 2006). In April 2003 the plateau experienced a wildfire over an area of $5.5 \mathrm{~km}^{2}$ that left the peat soils within the burnt area bare and without vegetation. The area has a history of wildfires and the causes and risks of wildfires in the region are discussed in (Albertson et al., 2009) and the fire properties typical of the region are outlined in Santana and Marrs (2014). As a result the area has become the focus of extensive revegetation with work on the sites in the study beginning in the summer of 2003 - four years before the start of monitoring. Here we consider the effect of revegetation of wildfire affected sites on the DOC concentration of peatland soils although the sites were also heavily eroded prior to fire and so restoration was also planned to tackle that legacy.

Study sites were chosen to cover the range of restoration types present across the Bleaklow Plateau with two ages since revegetation ( 1 and 4 years since treatment). The details of the sites are outlined in Table 1. All the study sites were ombrotrophic, blanket bog systems. The revegetation was conducted using an application of lime and fertiliser treatment in combination with nurse grass seed mixture (Festuca spp., Deschampsia spp. and Agrostis spp.). To stabilise the peat surface heather brash (Calluna vulgaris) was used on flat surfaces while steeper gully slopes were covered with geojute, textile netting. In addition to the restored sites the study included three control sites (Table 1). One control site was vegetated; had been unaffected by the April 2003 wildfire; and would be acceptable as an endpoint of revegetation - the control site is dominated by Eriophorum spp. ( $\mathrm{Ne}$ - Table 1). The other two controls were bare soil sites affected by the fire (Uf and $\mathrm{Ug}$ - Table 1) which have had no restoration treatment and were left as bare peat areas, one gullied $(\mathrm{Ug})$ and the other flat $(\mathrm{Uf})$.

\subsection{Plot scale measurements}

Within each selected site (restored and control) two plots were chosen and the project installed three dipwells in each plot. The equipment allowed for soil water quality and water table measurement to be made in triplicate in each plot and sixfold in each type of restoration or control site. Worrall et al. (2007a) showed that, when considering the effect of rotational heather burning and grazing upon water table and soil water composition, such a design had sufficient statistical power to demonstrate significant differences between management treatments and to measure the size of the effect made by each management technique based upon monthly sampling over one year. Dipwells were sited along semi-stratified transects within each plot with respect to any topography within the plot and given the constraint that none will be sited within $2 \mathrm{~m}$ of the edge of any treatment. The dipwells were installed using the same size tubing as the dipwells: this was done so as to remove the minimum amount of peat when installing the dipwells and create the best possible natural seal between the soil and the dipwell. All dipwells were left to settle for at least 1 month prior to any sampling.

All plots were visited and sampled on a monthly basis between November 2006 and January 2012 except for periods when heavy snowfall prevented access (January 08, February 10, December 12) and when no person was available to collect and analyse sample (July 09, September 09, April 10, May 10). The final year of the project (November 2011 to January 2012) included only three months. The final months of the project were included so that adequate winter coverage could be included in the analysis.

The soil water samples do not necessarily represent the DOC concentration that would occur in the streams from the restored plots. Therefore, for the final 15 months of the experiment from November 2010 to January 2012 samples of flowing water (stream runoff samples) were taken for those plots where there was a stream flowing from the sites (Ne, Uf, Ug and R4 - Table 1). In addition an automatic water sampler was situated on the stream flowing between the plots of the vegetated control $(\mathrm{Ne})$.

\subsection{Water analysis}

Soil porewater from the dipwells and all stream runoff samples were analysed for $\mathrm{pH}$, conductivity, absorbance at 400,465 and 


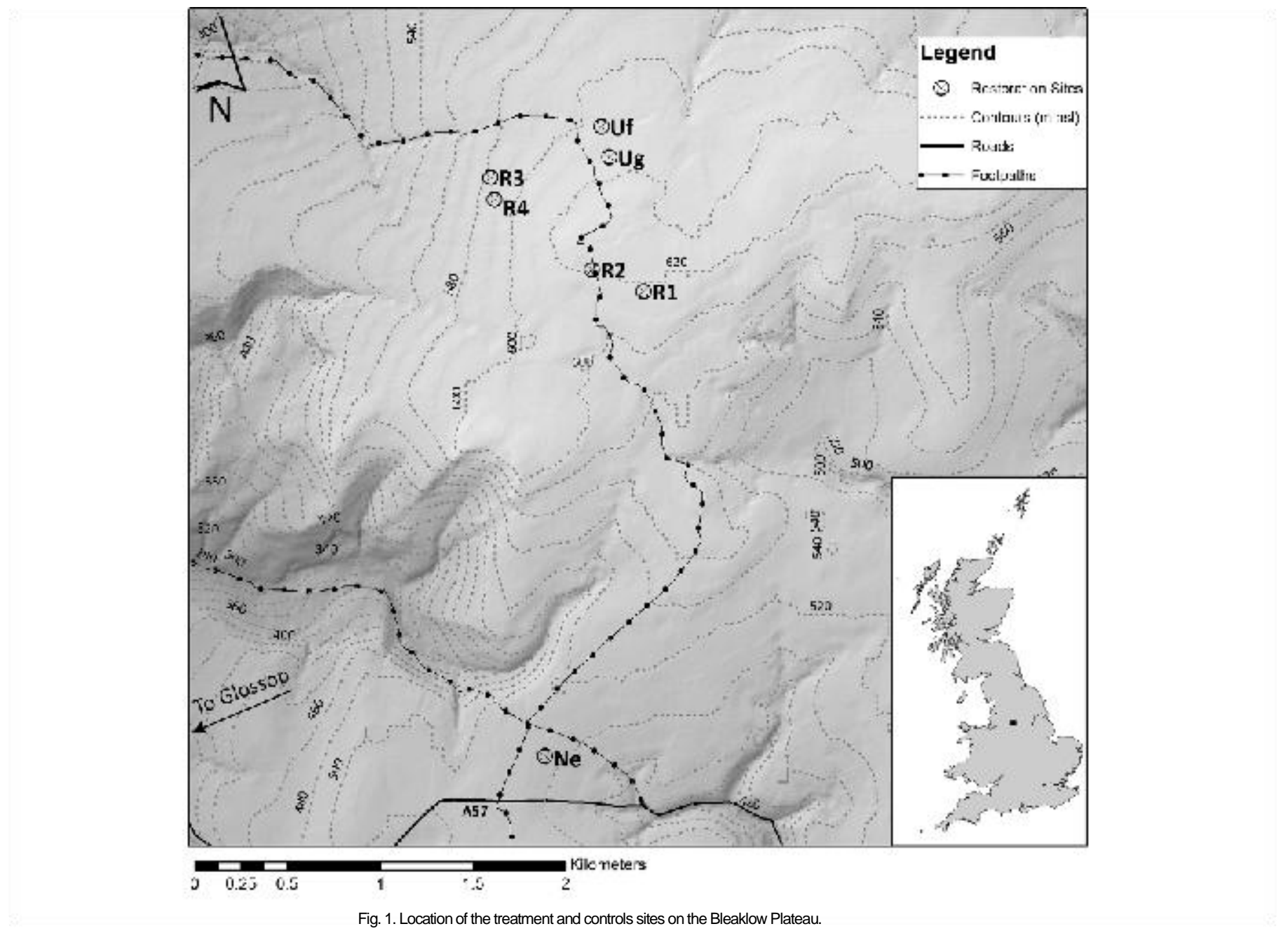

Table 1

The sites chosen for the study and details of the restoration treatments used on the site.

\begin{tabular}{|c|c|c|c|c|c|c|c|c|}
\hline \multicolumn{3}{|c|}{ Site Description Control type } & \multicolumn{2}{|c|}{ Seeded Limed Fertiliser } & \multicolumn{4}{|c|}{ Topo Age Vegetation Clay et al. (2012) Dixon et al. (2014) } \\
\hline Ne & Control & Vegetated & & & Flat & na $U$ & Natural channel & LD-F \\
\hline $\mathrm{R} 1$ & Restored & & $\mathrm{U}$ & $\cup \cup$ & Flat & $1 \mathrm{U}$ & & SHF \\
\hline $\mathrm{R} 2$ & Restored & & $\cup$ & $\cup \cup$ & Flat & $1 U$ & & SLHBG \\
\hline R3 & Restored & & $\cup$ & $\cup \cup$ & Flat & $4 U$ & & \\
\hline R4 & Restored & & $\cup$ & $\cup \cup$ & Gully & $4 U$ & Revegetated gully & SLGe-G \\
\hline Uf & Control & Bare soil & & & Flat & na & & B-f \\
\hline Ug & Control & Bare soil & & & Gully & & Bare soil gully & $B-G$ \\
\hline
\end{tabular}

$665 \mathrm{~nm}$ (Abs400, Abs465 and Abs665) and DOC concentration. All samples were filtered prior to analysis using $0.45 \mathrm{~lm}$ syringe filters. The $\mathrm{pH}$ and conductivity were measured using electrode methods. Absorbance measurements were taken for a basic colour reading (Thurman, 1985) on a Jenway 6505 spectrophotometer. Concentrations of DOC were measured colourimetrically using the method of Bartlett and Ross (1988). By measuring both Abs 400 and DOC, specific absorbance, i.e. absorbance to carbon ratio, could be evaluated. In addition, the E4/E6 ratio (ratio of Abs465 to AbS665), was calculated on all samples. This ratio can be used to measure the relative proportions of fulvic acid to humic acid in the coloured component of the DOC and also measure the degree of humification (Thurman, 1985). Chen et al. (1977) have shown that the $E 4 / E 6$ ratio is mainly governed by the particle size or molecular weight; and is affected by $\mathrm{pH}$. The $\mathrm{pH}$ of all water samples was included as a covariate in the analysis. Therefore, this study could consider two measures of DOC composition alongside concentration.

\subsection{Water table}

Water table was monitored at networks of dipwells placed on each plot. Dipwells were made from $5 \mathrm{~cm}$ diameter plastic pipe with holes drilled at regular intervals down to $1 \mathrm{~m}$ and inserted vertically into the peat profile. Water table depth was measured in each of the dipwells on each of the sites every month during the study.

\subsection{Vegetation monitoring}

Duplicate vegetation surveys were carried out on two, $1 \mathrm{~m}^{2}$ quadrants in fixed positions on each site. The vegetation survey 
results cannot be used as covariate within the ANOVA because the results are identical for every measurement within each site and different between plots. However, the differences in vegetative community between the sites can be used in explaining any between-site differences observed. Separately, the dominant vegetation type around each dipwell installed to sample the soil water was surveyed with $0.25 \mathrm{~m}^{2}$ quadrats around each dipwell. Additionally, random quadrat surveys were conducted for each site at the end of the study (April 2012).

\subsection{Statistical analysis}

The sampling survey design implemented in this study represents a factorial approach to the problem of understanding the impact of revegetation on the DOC concentrations in peatlands. This study can be considered as a four-factor experiment. The first factor was the difference between project years, and has six levels. The second factor was the sampling month and had 12 levels - one for each calendar month. The third factor was the difference between sites and had up to six levels - although there were seven sites considered data were always judged relative to one or other control site. Although the final project year contained only three months of data the study was a complete factorial with respect to these three factors and so the effect of year can be judged. However, whenever effect size was judged project year 1 was compared to project year 5 and not project year 6, i.e. the first and last complete years of data were compared. Finally, although the experiment is crossed classified with respect to these factors the difference between dipwells can also be considered but as a nested factor within the site factor. The use of the difference between the dipwells was considered as a nested factor allowed the study to directly assess whether the variation within site was greater than the variation between sites. The study considered, where appropriate, a range of covariates within the analyses. These covariates were: $\mathrm{pH}$, conductivity, and depth to water table and were considered both untransformed and log-transformed. The analysis was performed with and without covariates so as to test whether any differences existed and, if so, whether they could be explained by the available covariate measurements.

This study could not directly consider restoration treatment as a factor because restoration treatment was never repeated between sites, i.e. no combinations of site and treatment were available on the Bleaklow Plateau. Equally, no measurements were made prior to the fire because it could not be known when or where the wildfire would have occurred nor were any measurements made prior to restoration treatment, i.e. any differences identified between sites could be ascribed to pre-existing differences between sites rather than to restoration. Given the necessity of the design how then is it possible to demonstrate the effect of restoration upon $\mathrm{DOC}$ concentration? If restoration has had an effect upon DOC concentrations then there would be a significant change over the course of the experiment relative to the controls. Any significant shift relative to the controls can be assessed in several ways. Firstly, the measurements for any month on a restored site can be expressed relative to the average of the same measure for that month from either of the control types considered within the experiment. This relative assessment was performed and analysed in two ways. It was predicted that successful restoration would mean that restored sites become progressively more like vegetated control, i.e. relative values of any measure would become indistinguishable from 1 over time, and so data from treated sites were assessed relative to vegetated controls. Second, successful restoration would mean that restored sites become increasingly less like the bare soil, unrestored controls. Therefore, data from restored sites were also assessed relative to bare soil controls where it was predicted that relative values become progressively different from 1. Therefore, two sets of ANOVA were performed one relative to the vegetated control $(\mathrm{Ne})$ and one relative to the bare soil controls ( $U f$ and $\mathrm{Ug}$ ) and each of these ANOVA were considered with and without covariates. Given that in the absence of pre-fire and pre-restoration control then the test of importance will be the interaction between the site and project year factors to see whether this interaction is significant and whether it becomes more or less similar to 1 with time over the project. Thirdly, given that the measure of interest is DOC concentration the aim of restoration must also be to actually lower $\mathrm{DOC}$ concentrations and the final assessment is that absolute values become progressively smaller over time.

In addition to testing differences in soil water DOC concentration this study must also consider whether soil water DOC concentrations were related to runoff concentrations for the study sites. An ANOVA was performed in which the following factors could be considered. First, sample type, with two factor levels: either soil water or runoff water. Second, month with 12 levels, one for each month of the year. Third, site, with 4 levels (Ne, Uf, Ug and R4). There was no year factor as the sampling of runoff DOC was conducted only for one year of the overall experiment. Analysis was performed with and without covariates where the covariates were as above except depth to water table could not be included as runoff samples could not be directly associated with a water table measurement. Additionally, a principal component analysis (PCA) was performed using all the runoff water analysis in comparison to all the soil water analyses for all the same sites and over the same period. Principal component analysis was used to identify any possible mixing relationships between the soil and the runoff water. Worrall et al. (2006) have used principal component analysis to identify end members in the composition of soil and runoff water from an English peat bog and found that three end-members described changes in soil and runoff water with two soil water end-members and one runoff water end-member.

The statistical significance of the independent factors and interactions was determined using a general linear modelling approach based on an analysis of variance. The magnitude of the effects, in this case generalised $x^{2}$ (Olejnik and Algina, 2003), of each significant factor and interaction were calculated. Post-hoc testing of the results between factor levels, using Tukey's pairwise comparisons, was conducted to assess where significant differences lie between factor levels. There are several assumptions associated with using the ANOVA approach. Firstly, dataset variation between factors should be homogeneous and the data should be normally distributed, this was tested using Levene's test and the Anderson-Darling test for homogeneity of variance and normality respectively; if either of these tests were failed then the data were log-transformed and the re-tested for normality. Secondly, to avoid type I errors all probability values were given even if significance were assessed at the $95 \%$ level. Thirdly, as outlined above the power of the design was not tested in this case the number of replicates and length of study are based upon the design of Worrall et al. (2007a) where the experimental design used in this study was shown to have sufficient statistical power to distinguish between different land managements on peat within one year. Fourthly, the measurements made monthly may not be independent of each other and so invalidate the use of month as a factor. To test this the soil water DOC concentration from each well was considered as a time series using the approach of Worrall and Burt (1998) by which the times was detrended and deseasoned and the residual tested for independence by calculating the best fit AR process up to 5 lags, i.e. testing whether data from any one month for any one dipwell was significantly related to the data from well for up to five months afterwards. A similar argument could be applied to the year factor, but if months are independent of each then it follow that years are and also Worrall et al. (2007b) demonstrated 
that even after a 1 in 33 summer drought the impact did not persist through the first winter after the drought.

All significance tests were considered at $95 \%$ probability of being different from zero (probability of being zero < 0.05 ) unless otherwise stated. All statistical modelling was performed using Minitab v16 (Minitab Itd, Coventry, UK).

\section{Results}

Over the course of the study it was possible to measure the DOC concentration in 1061 samples and the depth to the water table 1676 times. The vegetation and observed data from each site is detailed in Tables 2 and 3 . Compared to the vegetated control $(\mathrm{Ne})$ the restored sites show a considerable difference in water table depths (Fig. 2) with the restored sites and bare soil controls having much deeper water tables and over the five complete years of the study the depth to the water table declined still further for two of the restored sites (R1 and R4) but not for the third (R2). The picture was less clear for soil water pH (Fig. 3) with very similar ranges of soil water $\mathrm{pH}$ between restored and vegetated controls. Soil water conductivity was larger on the restored sites and on the bare soil controls compared to the vegetated control, and over the five year period soil water conductivity rose at all sites (Fig. 4). Soil water DOC concentration appears to have been higher on the vegetated control in year 1 of the experiment than all other sites. But DOC rose for all sites over the 5 year period and there were greater rises for restored and bare soil controls than the vegetated controls (Fig. 5). Rises were observed for 4 out of the 5 complete years of the study, only in year 4 of the study was a decline observed and that was only relative to year 3 .

The data for relative water table, conductivity and DOC concentration (soil and runoff water) all had to be log transformed to meet the requirement of normality for ANOVA: this was not required for relative $\mathrm{pH}$. The time series analysis of the relative soil water DOC concentration for each dipwell showed no significant autoregressive components and so the monthly sampling could be assumed to be independent.

Table 2

Results of vegetation survey, November 2007.

\begin{tabular}{|c|c|c|c|c|c|c|c|}
\hline Site & $\%$ cover & $\%$ bare & Festuca & Deschampsia & Agrostis & Hypnum & Eriophorum \\
\hline $\mathrm{Ne}$ & 98 & 2 & & 50 & & & 44 \\
\hline R1 & 25.5 & 74.5 & 2.5 & & 22 & & 1 \\
\hline $\mathrm{R} 2$ & 33 & 65.5 & 28 & 2 & 1 & 3 & 3 \\
\hline $\mathrm{R} 4$ & 75.5 & 24.5 & 26 & 6.5 & 4 & & 2 \\
\hline Uf & & 100 & & & & & \\
\hline Ug & & 100 & & & & & \\
\hline
\end{tabular}

Table 3

The 5 th to 95 th percentile range of the observed data for each restoration treatment and control.

\begin{tabular}{|c|c|c|c|c|c|c|c|}
\hline \multirow{2}{*}{$\frac{\text { Site }}{\mathrm{Ne}}$} & \multicolumn{2}{|c|}{ Description Water table } & \multirow{2}{*}{$\frac{\mathrm{pH}}{3.9-5.9}$} & \multirow{2}{*}{$\frac{\text { Conductivity }}{22-78}$} & \multirow{2}{*}{$\frac{\mathrm{DOC}(\mathrm{mg} \mathrm{C} /)}{5.2-166}$} & \multirow{2}{*}{$\begin{array}{l}\text { Specific absorbance (Abs400_10 }{ }^{3} \text { ) } \\
0.6-15.9\end{array}$} & \multirow{2}{*}{$\begin{array}{l}\text { E4/E6 } \\
1.7-9.7\end{array}$} \\
\hline & Control & $1.7-9.0$ & & & & & \\
\hline $\begin{array}{l}\mathrm{R} 1 \\
\mathrm{R} 2\end{array}$ & $\begin{array}{l}\text { Restored } \\
\text { Restored }\end{array}$ & $\begin{array}{l}8.9-51.9 \\
0.4-51.8\end{array}$ & $\begin{array}{l}3.6-5.0 \\
3.7-5.7\end{array}$ & $\begin{array}{l}24-116 \\
20-87\end{array}$ & $\begin{array}{l}9.3-179 \\
13.0-177\end{array}$ & $\begin{array}{l}0.9-16.0 \\
0.5-8.2\end{array}$ & $\begin{array}{l}2.0-19.5 \\
1.8-17.2\end{array}$ \\
\hline $\begin{array}{l}\text { R4 } \\
\text { Uf }\end{array}$ & $\begin{array}{l}\text { Restored } \\
\text { Control }\end{array}$ & $\begin{array}{l}11.6-48.8 \\
10.5-58.6\end{array}$ & $\begin{array}{l}3.8-5.4 \\
3.6-5.1\end{array}$ & $\begin{array}{l}21-84 \\
31-118\end{array}$ & $\begin{array}{l}9.7-227 \\
22.0-243\end{array}$ & $\begin{array}{l}0.4-11.4 \\
1.1-11.3\end{array}$ & $\begin{array}{l}2.4-18.4 \\
2.1-15.7\end{array}$ \\
\hline Ug & Control & $12.9-54.0$ & $3.7-5.0$ & $30-103$ & $15.0-202$ & $0.9-9.1$ & $2.7-13.0$ \\
\hline
\end{tabular}

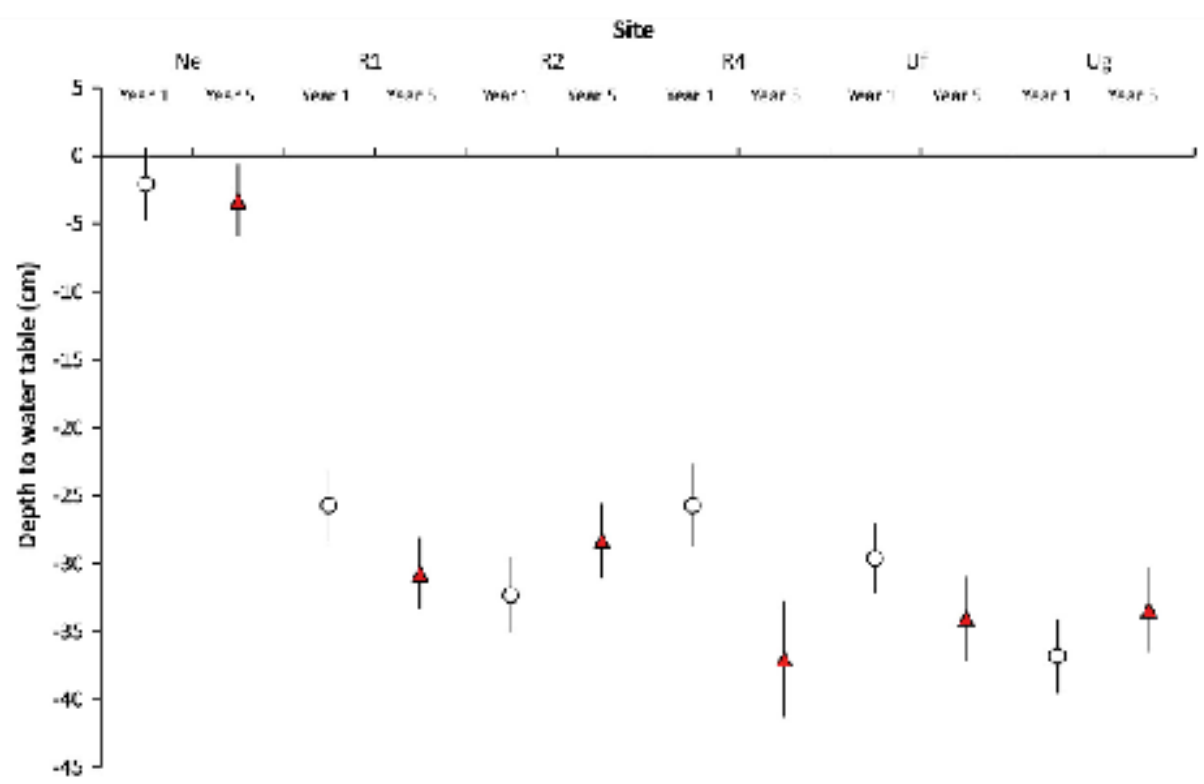

Fig. 2. The arithmetic mean and $95 \%$ confidence interval of year 1 and year 5 observations of the depth to water table for each control and treated site, where s represents year 1 average and $N$ represents the year 5 average. 


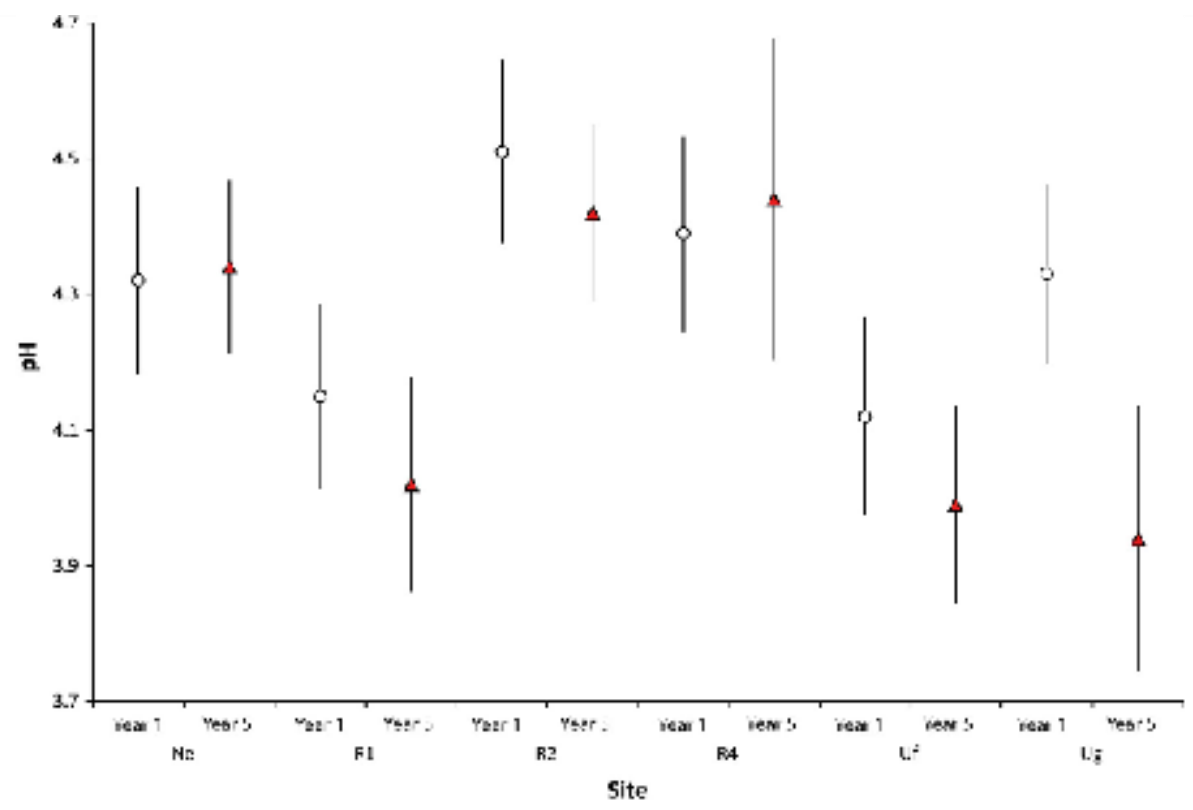

Fig. 3. The arithmetic mean and $95 \%$ confidence interval of year 1 and year 5 observations of the soil water pH for each control and treated site, where s represents year 1 average and $\mathrm{N}$ represents the year 5 average.

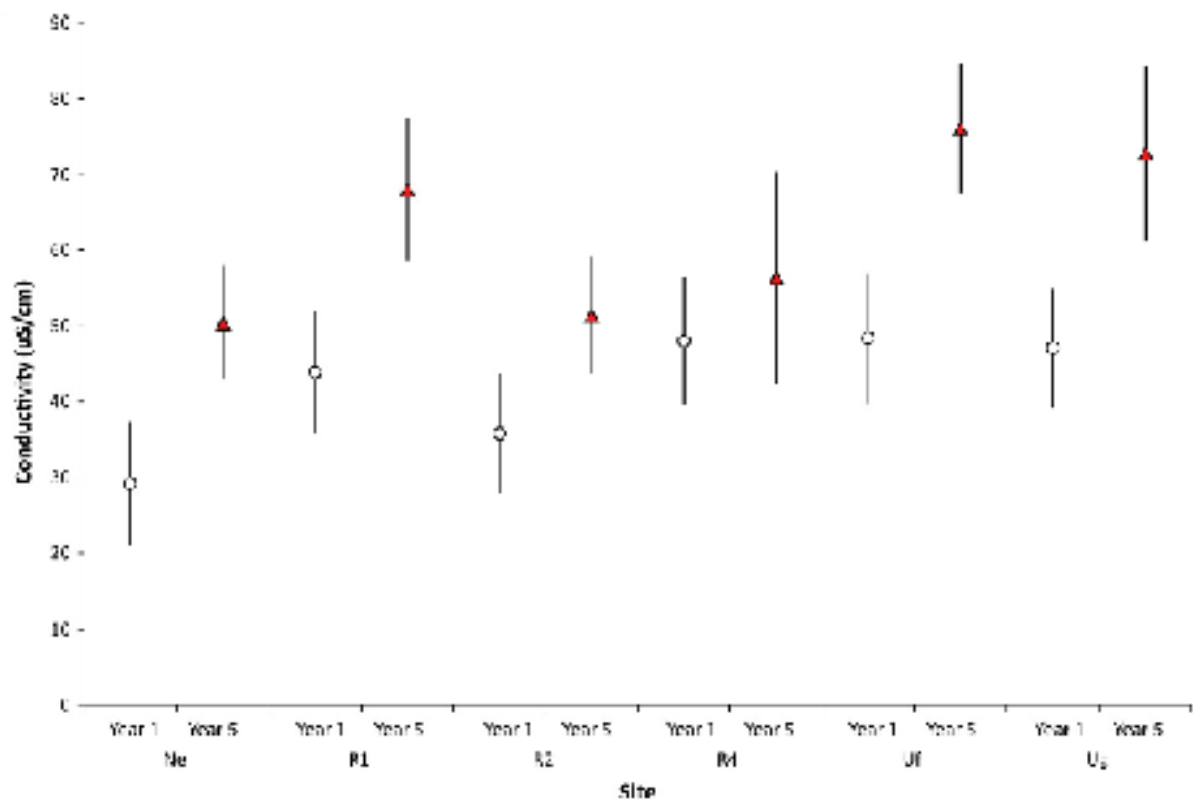

Fig. 4. The arithmetic mean and $95 \%$ confidence interval of year 1 and year 5 observations of the soil water conductivity for each control and treated site, where s represents year 1 average and $\mathrm{N}$ represents the year 5 average.

\subsection{Restoration relative to the vegetated control}

The water table could be measured 1604 times for this comparison but no significant difference was found between sites. It should be remembered that it was relative water table depth that was being analysed and so this suggests that water table depth was not different between the restored sites and the bare soil control sites. Equally, by analysing data relative to one of the control sites and siting dipwells to take account of topography differences over time in relative water table cannot be ascribed to topography The lack of a significant site factor does not mean that the sites all have the same depth to water table as the vegetated control furthermore there was no significant interaction between the site and project year (Table 4) implying that relative relationship between the depth to water table on the vegetated control and that on the restored and bare soil control sites did not change with time in the project. The median depth to the water table on the vegetated control was $0.5 \mathrm{~cm}$ below surface whereas for the restored sites it was $30.8 \mathrm{~cm}$ below the surface and $34.3 \mathrm{~cm}$ below the surface for the bare soil controls. The factor which explained the greatest proportion of the original variance was month, i.e. the seasonal variation in the depth to water table was greater than variation between years. The lack of a significant interaction between site and project years shows that there was no significant improvement in the water table of the restored sites relative to the vegetated control over the course of the project. Given the nature of the timing of 


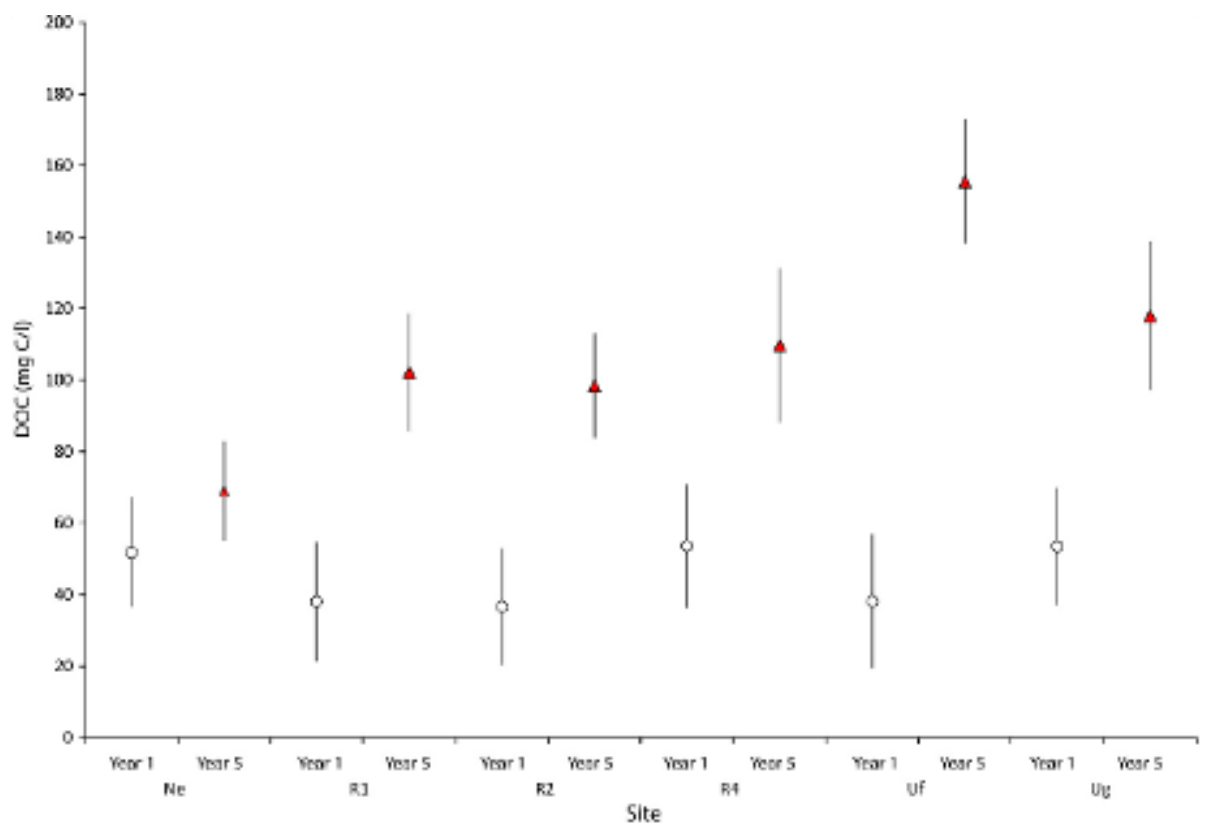

Fig. 5. The arithmetic mean and 95\% confidence interval of year 1 and year 5 observations of the soil water DOC concentration for each control and treated site, where s represents year 1 average and $\mathrm{N}$ represents the year 5 average.

Table 4

The results of the ANOVA relative to the vegetated control.

\begin{tabular}{|c|c|c|c|c|c|c|c|c|c|c|}
\hline \multirow[b]{3}{*}{$\begin{array}{l}\text { Factor/interaction/ } \\
\text { covariate }\end{array}$} & \multicolumn{10}{|c|}{ Proportion of variance } \\
\hline & \multicolumn{3}{|c|}{ Water table $\mathrm{pH}$} & \multicolumn{2}{|c|}{ Conductivity } & \multicolumn{2}{|l|}{ DOC } & \multicolumn{2}{|c|}{ Specific absorbance } & \multirow{2}{*}{$\begin{array}{l}\text { E4/E6 } \\
\text { Without } \\
\text { covariates }\end{array}$} \\
\hline & $\begin{array}{l}\text { Without } \\
\text { covariates }\end{array}$ & $\begin{array}{l}\text { Without } \\
\text { covariates }\end{array}$ & $\begin{array}{l}\text { With } \\
\text { covariates }\end{array}$ & $\begin{array}{l}\text { Without } \\
\text { covariates }\end{array}$ & $\begin{array}{l}\text { With } \\
\text { covariates }\end{array}$ & $\begin{array}{l}\text { Without } \\
\text { covariates }\end{array}$ & $\begin{array}{l}\text { With } \\
\text { covariates }\end{array}$ & $\begin{array}{l}\text { Without } \\
\text { covariates }\end{array}$ & $\begin{array}{l}\text { With } \\
\text { covariates }\end{array}$ & \\
\hline Site & - & 18.8 & 14.0 & 35.7 & 23.7 & 6.1 & 7.5 & & & 17.9 \\
\hline Year & 11.2 & 6.0 & 6.5 & 12.6 & 12.5 & 28.5 & 22.7 & 42.3 & 41.6 & 49.8 \\
\hline Month & 85.6 & 48.2 & 49.7 & 31.0 & 31.6 & 24.3 & 24.7 & 51.1 & 46.8 & 8.9 \\
\hline Collar & - & 4.5 & 3.7 & 2.8 & 4.0 & 6.8 & 11.9 & - & - & 1.4 \\
\hline Site/Year & & 10.0 & 9.4 & 5.1 & 8.5 & 5.5 & 0 & & & 11.6 \\
\hline $\log _{e}($ rel.WTD) & & & 1.5 & & 20 & & 3.2 & & 5.1 & \\
\hline $\begin{array}{c}\log _{\mathrm{e}}(\text { re.cond) and } \\
\log _{\mathrm{e}}(\mathrm{rel} . \mathrm{pH})\end{array}$ & & & 3.3 & & 3.7 & & 1.2 & & & \\
\hline Emor & 3.2 & 12.4 & 11.9 & 12.7 & 13.9 & 28.8 & 28.8 & 6.6 & 6.6 & 20.4 \\
\hline
\end{tabular}

the monitoring after the inception of restoration it was possible that the impact of restoration occurred before the monitoring started but even so it was not sufficient to restore water table to the values of the vegetated control or to show significant continuing improvement. There were no covariates that could be considered in the analysis of the depth to water table.

For the soil water $\mathrm{pH}$ there were 692 measurements that could be compared to the vegetated control. For pH the most important factor was also the difference between months, followed by the site factor and then the difference between project years (Table 4). There was a significant interaction between site and project year factors but for two of the restored sites (R2 and R4) the soil water $\mathrm{pH}$ declined relative to the vegetated control and for one site the soil water $\mathrm{pH}$ rose (R1), for the bare soil controls the $\mathrm{pH}$ declined relative to the vegetated control. Inclusion of the covariates increased the importance of all the factors explaining the variation in $\mathrm{pH}$ but the inclusion of covariates did not change the pattern of the interaction of site and project year factors. In project year 1 the $\mathrm{pH}$ of the soil water on the restored sites was on average $3 \%$ lower than that on the vegetated control ( $\mathrm{pH}=4.32$ compared to 4.45$)$. In year 1 the restored sites have an average $\mathrm{pH} 97 \%$ of the vegetated control and in year 5 this had increased slightly to $99 \%$ of the vegetated control ( $\mathrm{pH}=4.41$ compared to 4.46$)$.
For the soil water conductivity there were 686 samples that could be compared to the vegetated control. The proportion of original variance explained by the factors for conductivity was similar to that of $\mathrm{pH}$ with a significant interaction between site and project year with the average soil water conductivity of the restored sites being $25 \%$ higher than the vegetated control in project year 1 and this difference declined to only $16 \%$ greater by project year 5 . The median soil water conductivity for the vegetated control was $42.6 \mathrm{IS} / \mathrm{cm}$ while for the bare soil controls and restored sites it was $49.9 \mathrm{IS} / \mathrm{cm}$, however, when covariates were included then there was a pattern of significant improvement of conductivity, i.e. the soil water conductivity of the restored sites did become more like the vegetated control over the course of the study.

It was possible to measure the soil water DOC concentration 665 times relative to the values observed for the vegetated control. When ANOVA was performed without the inclusion of covariates then all single factors were found to be significant (Table 4). The most important single factor was difference between years with the relative DOC concentration increasing over the study period but with a distinct decline in project year 4 (November 2009 to October 2010). The next most important factor was the month and since this is the relative concentration being considered then a significant difference between months means that the restored 
and control sites have difference responses across the year but an examination of the main effects plot for the month factor shows no clear seasonal cycle. Dipwell was included as a nested factor within the site factor to test whether intra-site variation was greater than inter-site variation and indeed in this case the amount of the original variance explained by the nested dipwell factor was marginally greater than that due to the site factor (6.8 compared to $6.1 \%$ respectively). The site factor shows that all sites had higher soil water DOC concentrations than the vegetated control. There was one significant interaction, that between site and year, and this shows that for none of the sites considered relative to the vegetated control was the value of soil water DOC concentration lower in year 5 or 6 than it was in project year 1 . Only in year 4 was a significant decline observed and then only relative to year 3 results but not relative to year 1 results (Fig. 6). In year 1 the soil water DOC concentration of the sites considered was on average $16 \%$ lower than on the vegetated control but in year 5 the average soil water concentration was $52 \%$ greater than the vegetated control. When only the restored sites are considered the average change over the period was between $20 \%$ less than the vegetated control to $34 \%$ greater than the vegetated control.

When covariates were included two covariates were found to be significant - relative water table depth and relative soil water conductivity. For both significant covariates there was a positive correlation with relative $\mathrm{DOC}$ concentration, i.e. relative $\mathrm{DOC}$ concentration increased with increasing depth of the water table and increasing soil conductivity. Upon inclusion of the covariates into the ANOVA the overall proportion of variance explained increased and in particular the proportion of the variance explained by the site and month factors. Conversely, the proportion of the original variance explained by the year factor decreased. With the inclusion of covariates the importance of intra-site variation increased relative to inter-site variation, i.e. there was a greater variation in DOC concentration within a site when the averaging of water table depths and soil water conductivity within sites was allowed for. Perhaps the most important consequence of including covariates was that the interaction between site and year factors was no longer significant this means that the change in $\mathrm{DOC}$ concentration relative to the vegetated control was explained by allowing for changes in water table depth and soil water conductivity.

When considering the entire time series of relative DOC concentration it was possible to calculate the best fit regression equation;

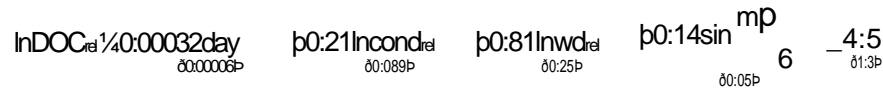

where day = the day number since the start of the experiment (day); condrel $=$ the soil water conductivity relative to that on the

Fig. 6. Box-whisker plot of the soil water DOC concentrations of the restored and bare soil sites relative to the vegetated control for the 5 complete project years. vegetated control (no units); wdrel = the depth to the water table relative to the vegetated control (no units); and $\mathrm{m}=$ month number (January $=1$ to December $=12$ ). Only variables found to be significant at the $95 \%$ probability or greater were included into the above equation and the values in brackets are the standard error in coefficients or constant term.

When individual sites were considered, however, there was no such relationship for R4 or R3, but R2, Uf and Ug had such a significant trend.

The study considered two measures of the DOC composition. For specific absorbance there was no significant difference between sites and no significant interaction between site and project years. The most important factor was the difference between months. The importance of the seasonal cycle in the specific absorbance has been previously demonstrated for soil water DOC (Worrall et al., 2007a). For the E4/E6 ratio data the most important factor was the difference between project years. There was a significant interaction between site and project year factors observed within the $E 4 / E 6$ data. On average in project year 1 the $E 4 / E 6$ ratio on the restored sites was $67 \%$ higher than the vegetated control and in project year 5 the restored sites were on average $55 \%$ higher than the vegetated control sites.

\subsection{Restoration relative to bare soil controls}

The depth to the water table could be measured 1370 times for this comparison. There was a significant interaction between the site factor and the project year and for all sites, including the vegetated control, the depth to the water table increased over the study relative to the bare soil controls (Table 5). The water table was, on average, $9 \%$ lower on the restored sites than the bare soil controls after the 5 years.

For soil water, $\mathrm{pH}$ was measured 717 times relative to the bare soil controls. There was a significant interaction between site and project factors and for all the restored sites the $\mathrm{pH}$ rose relative to the bare soil controls with an average rise of $110 \%$ relative to the bare soil controls over the study period. The important thing to note about this relative rise is that soil water $\mathrm{pH}$ declined on the bare soil treatments (average decline over 5 years of 0.26 , from 4.23 to 3.97 ) whereas for the restored treatments the $\mathrm{pH}$ declined from 4.35 to 4.29 over the same period. When the covariates were included the only significant covariate was the soil water conductivity and upon the inclusion of this as a covariate the interaction between site and project years became insignificant (Table 5). Therefore it is not surprising that when soil water conductivity was considered, a significant increase was observed for the restored sites relative to the bare soil controls.

The comparison of DOC concentration relative to the bare soil controls could be made 639 times. The ANOVA results show that all single factors were significant when considered without covariates. The single most important factor was month, the difference between experimental months within years. The second most important factor was year, the difference between experimental years. The least important single factor was difference between sites. Again the nested dipwell factor explained a larger proportion of the variance than the site factor showing that intra-site variation was greater than inter-site variation. One interaction was found to be significant, that between site and year (Fig. 7). Examining the record for each site shows that the average increase in DOC for the restored sties relative to bare soil controls was $11 \%$, there was no change relative to the vegetated control.

When covariates were included, three covariates were found to be significant; relative water table depth, soil water $\mathrm{pH}$ and soil water conductivity. The inclusion of covariates leads to an increase in the proportion of variance explained by site, month, year and dipwell factors, but the proportion of the variance explained by 
The results of the ANOVA relative to the bare soil controls.

\begin{tabular}{|c|c|c|c|c|c|c|c|c|c|c|c|}
\hline \multirow[b]{3}{*}{$\begin{array}{l}\text { Factor/ } \\
\text { interaction/ } \\
\text { covariate }\end{array}$} & \multicolumn{11}{|c|}{ Proportion of variance } \\
\hline & \multirow{2}{*}{$\begin{array}{l}\text { Water } \\
\text { table } \\
\text { Without } \\
\text { covariates }\end{array}$} & \multicolumn{2}{|l|}{$\mathrm{pH}$} & \multicolumn{2}{|c|}{ Conductivity } & \multicolumn{2}{|l|}{ DOC } & \multicolumn{2}{|c|}{ Specific absorbance } & \multicolumn{2}{|l|}{ E4/E6 } \\
\hline & & $\begin{array}{l}\text { Without } \\
\text { covariates }\end{array}$ & $\begin{array}{l}\text { With } \\
\text { covariates }\end{array}$ & $\begin{array}{l}\text { Without } \\
\text { covariates }\end{array}$ & $\begin{array}{l}\text { With } \\
\text { covariates }\end{array}$ & $\begin{array}{l}\text { Without } \\
\text { covariates }\end{array}$ & $\begin{array}{l}\text { With } \\
\text { covariates }\end{array}$ & $\begin{array}{l}\text { Without } \\
\text { covariates }\end{array}$ & $\begin{array}{l}\text { With } \\
\text { covariates }\end{array}$ & $\begin{array}{l}\text { Without } \\
\text { covariates }\end{array}$ & $\begin{array}{l}\text { With } \\
\text { covariates }\end{array}$ \\
\hline Site & 78.5 & Ns & 6.5 & 6.0 & 10.9 & 1.5 & 3.7 & 5.1 & 6.3 & 15.2 & 36.1 \\
\hline Year & 4.5 & 65.2 & 13.2 & 27.3 & 1.0 & 5.6 & 29.4 & 28.7 & 14.4 & 25.6 & 2.2 \\
\hline $\begin{array}{l}\text { Month } \\
\text { Collar }\end{array}$ & $\begin{array}{l}5.3 \\
-\end{array}$ & $\begin{array}{l}16.3 \\
\mathrm{Ns}\end{array}$ & $\begin{array}{l}12.5 \\
2.0\end{array}$ & $\begin{array}{l}54.4 \\
\text { Ns }\end{array}$ & $\begin{array}{l}4.1 \\
3.4\end{array}$ & $\begin{array}{l}33.6 \\
6.3\end{array}$ & $\begin{array}{l}11.3 \\
5.7\end{array}$ & $\begin{array}{l}40.4 \\
2.0\end{array}$ & $\begin{array}{l}33.3 \\
3.1\end{array}$ & $\begin{array}{l}41.8 \\
\text { Ns }\end{array}$ & $\begin{array}{l}8.3 \\
1.2\end{array}$ \\
\hline $\begin{array}{l}\text { Site/Year } \\
\text { loge(rel.WTD) }\end{array}$ & 6.7 & 14.9 & Ns & 3.9 & Ns & 24.9 & $\begin{array}{l}11.8 \\
1.1\end{array}$ & 9.9 & $\begin{array}{l}13.8 \\
2.2\end{array}$ & 7.1 & $\begin{array}{l}9.0 \\
1.5\end{array}$ \\
\hline $\begin{array}{l}\log _{e}(\text { rel.cond) } \\
\quad \text { and } \\
\quad \log _{e}(\text { rel.pH })\end{array}$ & & & 61.4 & & 74.3 & & & & 9.0 & & 29.4 \\
\hline Error & 5.0 & 3.4 & 4 & 7.6 & 5.6 & 28.1 & 23.1 & 14.0 & 17.9 & 7.2 & 12.3 \\
\hline
\end{tabular}

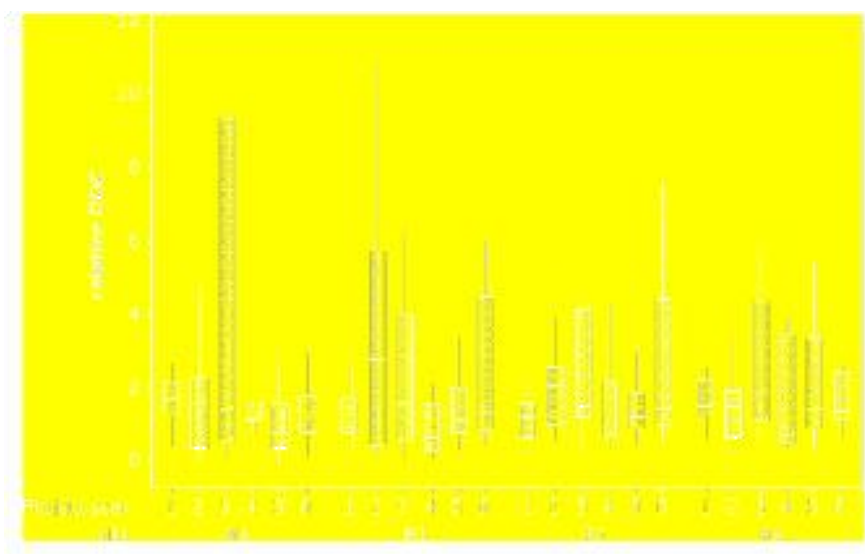

Fig. 7. Box-whisker plot of the soil water DOC concentrations of the restored sites and bare soil relative to the bare soil controls for the 5 complete project years.

the significant interaction between site and project year factors decreased from $25 \%$ to $11 \%$ and the interaction effect changes dramatically. When covariates were included then the nature of the site factor changed, relative DOC of the restored sites decreased over the course of the project with an average decrease over the study period of $90 \%$ relative to the bare soil controls decreases in relative soil water $\mathrm{DOC}$ were observed for all sites. The decrease in DOC concentration over the study period when differences in water table, $\mathrm{pH}$ and conductivity are accounted for means that if these had been accounted for in the restoration then $\mathrm{DOC}$ concentrations would have actually decreased.

\subsection{Absolute changes in soil water $\mathrm{DOC}$ concentration}

The third test used of the data was whether the absolute change in the $\mathrm{DOC}$ concentrations of the restored sites would be a decrease over time. However, a simple visual comparison of the data distributions shows that this has not been the case for any of the restored sites (Fig. 5). In fact the DOC concentration rose for all sites between project year 1 and 5 but the arithmetic mean increase for the vegetated control was $17.2 \mathrm{mg} \mathrm{C/l}(\mathrm{n}=242)$ while for restored sites the average (arithmetic mean) increase was $60.7 \mathrm{mg} \mathrm{C} / \mathrm{l}(\mathrm{n}=514)$ but for bare soil sites it was $90 \mathrm{mg} \mathrm{C} / \mathrm{l}$ $(n=305)$. It is possible that this trend is a manifestation of the wider trend in $\mathrm{DOC}$ concentrations observed for many sites across the UK and the northem hemisphere (e.g. Freeman et al., 2001) but over only such short time periods Worrall and Burt (2008) have shown that short-trends (years) can be very different to the long term trend (decades)

\subsection{Runoff vs. soil water}

It was possible to compare 62 stream runoff water samples (47 from $\mathrm{Ne}, 15$ from restored sites) to 155 soil water samples from four sites over 12 months. Visual comparison suggests no difference between the runoff and soil water samples for the restored sties and the bare soil controls (Fig. 8), there does appear to be a difference for the vegetated control with soil water DOC concentrations higher than runoff concentrations.

It was not necessary to transform the data prior to ANOVA and including covariates into the analysis made no significant difference to the analysis and so covariates were not considered further. In the ANOVA without covariates there were significant effects due to the site and month factors but no significant difference between types of sample, i.e. soil water and runoff water were the same. The mean DOC concentration of runoff samples was $91 \pm 8 \mathrm{mg} \mathrm{C} / \mathrm{l}$ and for soil water the DOC concentration was $105 \pm 6 \mathrm{mg} \mathrm{C} / \mathrm{l}$ with the error given as the standard error in the mean. Therefore, the ANOVA concludes that soil water DOC concentration was directly comparable to runoff water concentrations. These runoff concentrations are higher than might be expected, but it should be emphasised that these were taken in the gullies and channels associated with the plots and so were in close, spatial relationship with the dipwells for the soil water. Furthermore, although it was always running water that was sampled it would have rarely been anything other than baseflow.

The PCA showed that only one component had an eigenvalue $(\mathrm{k})$ greater than one and the first two components explained $83 \%$ of the original variance $(k=1.71,0.79,0.50$; for PC1, PC2 and PC3 respectively, Table 6). Both the first two components had strong loadings for $\mathrm{DOC}, \mathrm{pH}$ and conductivity with the first component describing increases in $\mathrm{DOC}$ with increasing conductivity and decreasing $\mathrm{pH}$ while the second component has increasing DOC concentration with increasing $\mathrm{pH}$ and decreasing conductivity. The critical evidence is that when scores on PC1 and PC2 are plotted for both soil and runoff water samples then the two types of

Table 6

The loadings on PC1and PC2

\begin{tabular}{lll}
\hline Determinand & PC1 & PC2 \\
\hline $\mathrm{DOC}$ & 0.48 & 0.87 \\
$\mathrm{pH}$ & 0.61 & 0.39 \\
Conductivity & 0.63 & -0.29 \\
\hline
\end{tabular}




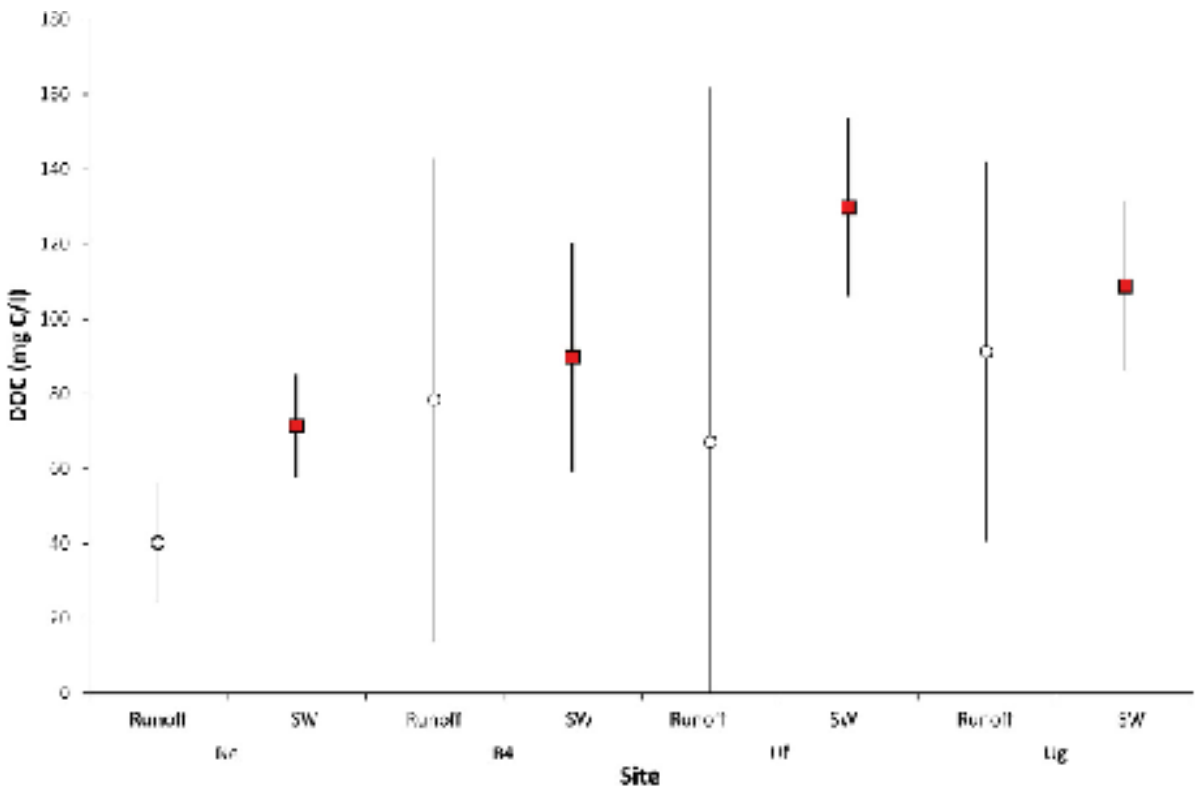

Fig. 8. The average and $95 \%$ confidence interval of the runoff and soil water DOC concentration for each control and treated site.

samples plot together and do not form distinct groupings based upon being sampled from runoff or soil water (Fig. 9). The soil water samples do distribute over a wider range of values than the runoff samples (see Fig. 9), but there were more soil water samples than runoff samples and the latter plot in a more restricted space circumscribed by the soil water samples. The main visual trend of the runoff water samples is from low $\mathrm{PC} 1 /$ high $\mathrm{PC2}$ to high PC1/low PC2 and follows a trend in the soil water samples.

\section{Discussion}

A possible explanation of the observed differences in soil water $D O C$ is that the observed differences were being driven by differences in the depth to the water table and soil water chemistry (esp. conductivity) that were themselves caused by changes in vegetation but also by incision within eroded peatlands. The average water table position for the vegetated control was $2.7 \mathrm{~cm}$ while that for the restored sites was $30 \mathrm{~cm}$. If the DOC concentration in soil water decreases towards the surface then as the average position of the water table rises it is accessing a lower concentration source of DOC. This may not only mean that the surface layers of peat are not good sources of DOC but also that higher in the soil profile the water is more likely to be mixed with rainwater and rainwater has a very low DOC concentration - reported ranges of DOC concentration in rainwater vary from 0.82 to $2 \mathrm{mg} \mathrm{C} / \mathrm{l}$ (Dawson and Smith, 2007). Alternatively, the reason for low DOC concentrations higher in the soil profile might be because DOC produced in these layers is more labile. It is also possible that burning could modify the surface properties of the peat by changing porosity (Clay et al., 2009b) or may change the hydrophobicity of the peat (Holden et al., 2014). This study does not necessarily need

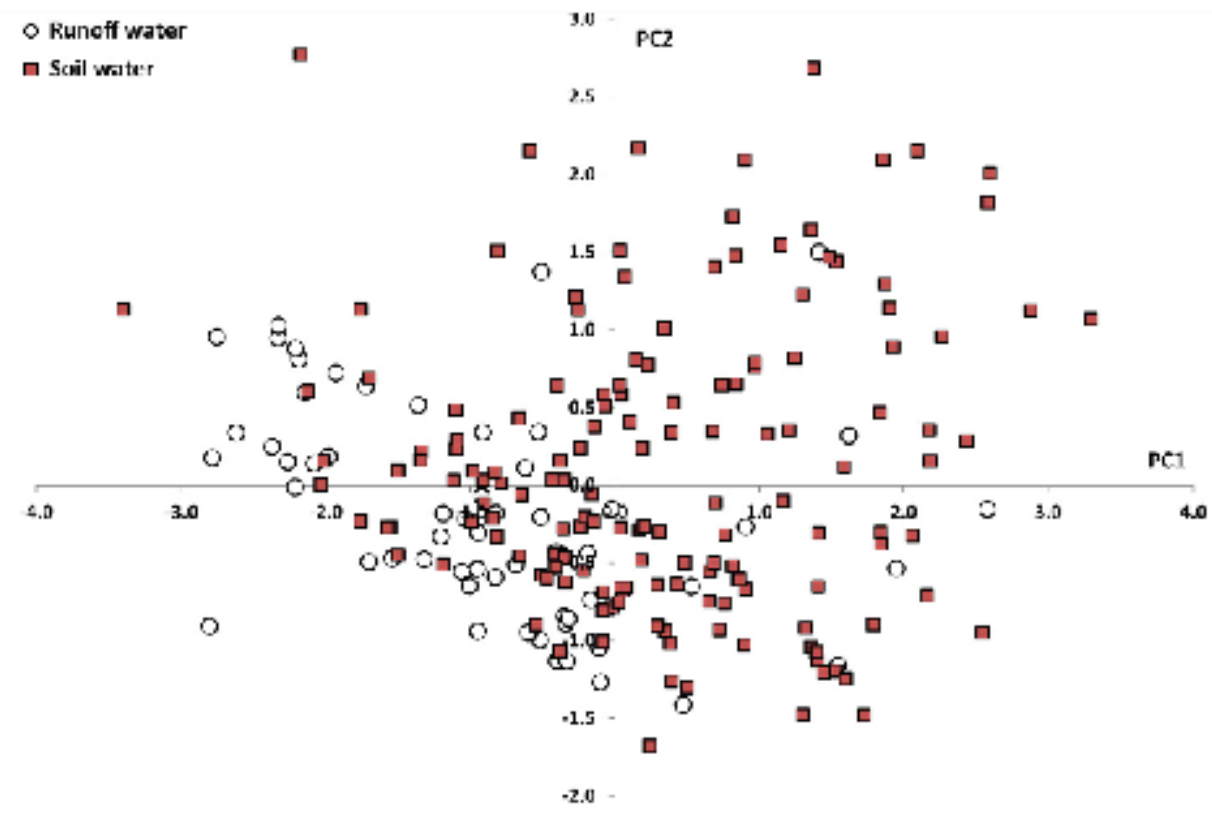

Fig. 9. The comparison of PC1 and PC2 for soil water and stream runoff samples. 
to invoke a change in DOC availability up the soil profile but instead invokes a simple mixing approach with a low DOC concentration end-member that represents rainwater and a high concentration DOC end member that represents deep soil water. Evidence for this end-member mixing interpretation comes from the fact that soil water conductivity is a significant covariate for the analyses considered. Deeper soil waters might be expected to have a high conductivity compared to rainwater which may be due to evaporative concentration as water tables decline or due to interaction with water from sub-peat, mineral layers. Therefore, this study would propose that the increases in DOC concentration observed by this study were not due to changes in production or the composition of the DOC rather they were due to changes in hydrology that mean pathways lower in the peat profile come to dominate after the wildfire and that these changes are not reversed by revegetation. Alternatively, the distinct hydrology of the restored sites could have been due to their highly eroded state prior to being de-vegetated by the April 2003 fire. This explanation of the variation in the observed DOC concentrations does not require a difference in DOC composition and indeed this study suggests that specific absorbance follows the DOC concentration. However, the E4/E6 ratio does show significantly higher values for restored sites compared to the vegetated control sites and this difference did decrease over the course of the study.

An alternative explanation is that DOC increases on restored sites is due to the increase in soil water $\mathrm{pH}$. The solubility of DOC increases with increasing $\mathrm{pH}$ (Lumsden et al., 2005) and this has been given an explanation for the widespread increases in streamwater DOC concentrations (Evans et al., 2012). However, in this study there was only a significant relationship compared to bare soil and not relative to the vegetated control. Bare soil soil water $\mathrm{pH}$ values decreased at time when DOC concentrations increased.

A number of studies have related DOC concentration in peat soil water to changes in water table depth (Clark et al., 2008). The blocking of drains in peat soils, as a means of raising water tables, has been extensively studied and the blocking of drains is, of course a means of raising water tables. Upon drain-blocking, Wallage et al. (2006) report a decline in DOC concentrations of surface waters; Worrall et al. (2007a) an increase; and Gibson et al. (2009) no significant change. Armstrong et al. (2010) combines data from an UK-wide survey of blocked and unblocked drains across 32 study sites and intensive monitoring of a peat drain system that has been blocked for seven years and found that water colour and DOC concentration were significantly lower in blocked drains with a mean difference of $28 \%$ compared to the open drains. Turner et al. (2013) found a significant decline in DOC concentration upon drain-blocking relative to controls of only $2 \%$ but the average change in water table depth across the site upon drainblocking was from only $6 \mathrm{~cm}$ depth to $5 \mathrm{~cm}$ depth, i.e. a small change in water table gave rise to a small change in DOC concentration. Burning and/or cutting of vegetation on peat soils have also been shown to raise water tables (Clay et al., 2009b). At the plot scale, Ward et al. (2007) and Clay et al. (2009a) found no significant difference in DOC concentrations in soil waters between burnt and unburnt sites while Worrall et al. (2007a) and Helliwell et al. (2010) showed a significant decrease in DOC concentration in soil water on burnt sites, and Worrall et al. (2013) found a significant decline in DOC in soil water for both the cutting and burning of vegetation. Clay et al. (2009a) was the only study to consider concentrations in surface runoff at the plot scale, and found no significant difference between burnt and unburnt plots. Clay et al. (2012) found no significant change in DOC concentration for burnt plots up to 10 years after burning, but there was a significant increase in water colour for up to 4 years after a plot was burnt. At a catchment-scale, the impact of burning has been observed to have differing effects (Yallop et al., 2008; Yallop and Clutterbuck, 2009; Chapman et al., 2010). Of course, this study is about the impact of vegetation development, rather than loss and the impact of both the erosive damage after a wildfire and revegetation was to lower the water table. If the observations for the impact of raising water tables in peat by changing management are reversible then the observations of increases in soil water DOC concentration observed here are consistent with changes seen for other managements. Indeed, it should be again noted that when variation due to the effects of the significant covariates (water table and conductivity) were allowed for then soil water DOC concentrations on restored sites were shown to be lower than those on the bare soil controls.

Lofgren et al. (2010) when comparing plot scale measurements with catchment scale measurements of DOC for sites undergoing recovery from acidification, found that although there was a consistent response at the plot scale to changing acidification there was not a consistent response at the catchment scale. However, this study shows that soil water DOC concentrations measured for the restored sites were reflected in the runoff concentrations of DOC, and therefore there would have been a worsening of water quality. Furthermore, shifts in DOC composition would have implications for the treatability of the stream water (Sharp et al., 2006). The study found no shift in specific absorbance but did find a change in $E 4 / E 6$ with higher $E 4 / E 6$ on restored sites but the difference between restored and vegetated sites did decrease over the course of the study: higher $\mathrm{E} 4 / \mathrm{E} 6$ ratios are associated with greater humic acid content of the DOC and larger molecular weight DOC is more readily removed compared to smaller and more hydrophilic components. The increase in vegetation can result in the increase of associated root exudates (Wallage and Holden, 2010) which could explain the initial increase of in $\mathrm{E} 4 / \mathrm{E} 6$. As the vegetation cover increased over the 5 years, there is also increased vegetation litter deposition, allowing the establishment of a litter layer thus increasing the production of more humic DOC components.

The object of restoration in this ecosystem was not predominantly for water quality but to preserve the peat ecosystem and the essence of a functioning peat ecosystem is an environment that is a continuing sink of carbon, not necessarily as a sink of greenhouse gases from the atmosphere. Worrall et al. (2011) estimated for a number of the restored sites considered in this study that the carbon sequestration benefit of peatland restoration would range between 122 and 833 tonnes $\mathrm{C} \mathrm{km}^{2} \mathrm{yr}^{-1}$. If the concentrations of $\mathrm{DOC}$ in soil water can be taken as representative of runoff water concentrations (e.g. Fig. 9) then it may also be the case that $\mathrm{DOC}$ export increases upon revegetation and so acting to negate the carbon benefits of revegetation. However, changes in DOC export are not just a matter of changes in concentration but also a matter of changes in the water yield. Revegetation would be expected to decrease water yield over that from bare soil because increased evaporation via transpiration from the plants, and indeed both Waddington et al. (2008) and Strack and Zuback (2013) found that DOC export was higher on the unrestored, cutover peatland compared to restored peatland due to changes in water yield.

Although this study could not comment on the benefit of individual restoration techniques used on the Bleaklow Plateau it was possible, from the ANOVA with covariates, to infer that had water tables been restored at the same time as revegetation, and had they been restored to levels equivalent to those observed on the vegetated controls then DOC concentrations would have actually decreased. This finding is complementary to the finding of Dixon et al. (2014) who showed, on the same sites, that decreasing water table depth would increase the rate of net primary production. 


\section{Conclusions}

This study considered two tests of the success of revegetation with respect to water quality and showed that relative to the vegetated control (the target of restoration) and the bare soil controls (the pre-restoration situation) the soil water DOC concentration rose. The study has shown that this would lead to an increase in at least the baseflow concentration of DOC from these restored catchments. However, the study shows that for comparable water table depths, soil water $\mathrm{pH}$ and conductivity the restoration would have achieved a lower concentration of DOC compared to unrestored sites. This study therefore, suggests that if revegetation were coupled with water table restoration and without liming then decreases in DOC concentration could be achieved.

\section{Acknowledgements}

This study was funded through the Moors for the Future Partnership and Natural England. We are grateful to Matt Buckler for advice on restoration treatment and study site location. The Peak District National Park ranger service assisted in the field survey, which was greatly appreciated.

\section{References}

Albertson, K., Aylen, J., Cavan, G., McMorrow, J., 2009. Forecasting the outbreak of moorland wildfires in the English Peak District. J. Environ. Manag. 90, 26422651.

Armstrong, A., Holden, J., Kay, P., Francis, B., Foulger, M., Gledhill, S., McDonald, A.T., Walker, A., 2010. The impact of peatland drain-blocking on dissolved organic carbon loss and discolouration of water; results from a national survey. $\mathrm{J}$. Hydrol. 381, 112-120.

Bartlett, R.J., Ross, D.S., 1988. Colorimetric determination of oxidizable carbon in acid soil solutions. Soil Sci. Soc. Am. J. 52, 1191-1192.

Bragazza, L., Freeman, C., Jones, T., Rydin, H., Limpens, J., Fenner, N., Ellis, T., Gerdol, R., Hajek, M., Hajek, T., Lacumin, P., Kutnar, L., Tahvanainen, T., Toberman, H., 2006. Atmospheric nitrogen deposition promotes carbon loss from peat bogs. Proc. Natt. Acad. Sci. 103 (51), 19386-19389.

Chapman, P.J., Macdonald, A.T., Tyson, R., Palmer, S.H., Mitchell, G., Irvine, B., 2010. Changes in water colour between 1986 and 2006 in the headwaters of the River Nidd, Yorkshire, UK. Biogeochemistry 101 (1-3), 261-294.

Chen, Y., Senesi, N., Schnitzer, M., 1977. Information provided on humic substances by E4-E6. Soil Sci. Soc. Am. J. 41, 352-358.

Clark, J.M., Lane, S.N., Chapman, P.J., Adamson, J.K., 2008. Link between DOC in near surface peat and stream water in an upland catchment. Sci. Total Environ. 404, 308-315.

Clay, G.D., Worrall, F., Fraser, E.D.G., 2009a. Effects of managed burning upon dissolved organic carbon (DOC) in soil water and runoff water following a managed burn of a UK blanket bog. J. Hydrol. 367, 41-51.

Clay, G.D., Worrall, F., Fraser, E.D.G., 2009b. Hydrological responses to managed burning and grazing in an upland blanket bog. J. Hydrol. 376, 486-495.

Clay, G.D., Worrall, F., Aebischer, N.J., 2012. Does prescribed burning on peat soils influence DOC concentrations in soil and runoff waters? Results from a 10 year chronosequence. J. Hydrol. 448-449, 139-146.

Condie, L.W., Smallwood, C.L., Laurie, R.D., 1983. Comparative renal and hepatotoxicity of halomethanes: bromodichloromethane, bromoform, chloroform, dibromochloromethane and methylene chloride. Drug Chem. Toxicol. 6, 563-578.

Dawson, J.J.C., Smith, P., 2007. Carbon losses from soil and its consequences for land-use management. Sci. Total Environ. 382, 165-190.

Dixon, S.D., Qassim, S.M., Rowson, J.G., Worrall, F., Evans, M.G., Boothroyd, I.M., Bonn, A., 2014. Restoration effects on water table depths and $\mathrm{CO}_{2}$ fluxes from climatically marginal blanket bogs. Biogeochemistry. http://dx.doi.org/10.1007/ s10533-013-9915-4

Evans, M.G., Warburton, J., Yang, J., 2006. Eroding blanket peat catchments: global and local implications of upland organic sediment budgets. Geomorphology 79 , 45-57.

Evans, C.D., Jones, T.G., Burden, A., Ostle, N., Zelinski, P., Cooper, M.D.A., Peacock, M., Clark, J.M., Oulehle, F., Cooper, D., Freeman, C., 2012. Acidity controls on dissolved organic carbon mobility in organic soils. Global Change Biol. 18 (11), 3317-3331.

Freeman, C., Evans, C.D., Montieth, D.T., Reynolds, B., Fenner, N., 2001. Export of organic carbon from peat soils. Nature 412, 785-786.

Freeman, C., Fenner, N., Ostle, N.J., Kang, H., Dowrick, D.J., Reynolds, B., Lock, M.A., Sleep, D., Hughes, S., Hudson, J., 2004. Export of dissolved organic carbon from Peatlands under elevated carbon dioxide levels. Nature 430, 195-197.

Gibson, H.S., Worrall, F., Burt, T.P., Adamson, J.K., 2009. DOC budgets of drained peat catchments. Hydrol. Process. 23, 1901-1911.
Gough, R., Holliman, P.J., Willis, N., Jones, T.G., Freeman, C., 2012. Influence of habitat on the quantity and composition of leachable carbon in the $\mathrm{O}_{2}$ horizon: potential implications for potable water treatment. Lake Reserv. Manage. 28, 282-292.

Helliwell, R.C., Britton, A.J., Gibbs, S., Fisher, J.M., Potts, J.M., 2010. Interaction effects of $\mathrm{N}$ deposition, land management and weather patterns on soil solution chemistry in a Scottish alpine heath. Ecosystems 13, 696-711.

Holden, J., Shotbolt, L., Bonn, A., Burt, T.P., Chapman, P.J., Dougill, A.J., Fraser, E.D.G. Hubacek, K., Inine, B., Kirkby, M.J., Reed, M.S., Prell, C., Stagl, S., Stringer, L.C., Turner, A., Worrall, F., 2007. Environmental change in moorland landscapes. Earth-Sci. Rev. 82, 75-100.

Holden, J., Wearing, C., Palmer, S., Jackson, B., Johnston, K., Brown, L.L., 2014. Fire decreases near-surface hydraulic conductivity and macropore flow in blanket peat. Hydrol. Process. 28 (5), 2868-2878.

Hsu, C.H., Jeng, W.L., Chang, R.M., Chien, L.C., Han, B.C., 2001. Estimation of potential lifetime cancer risk for trihalomethanes from consuming chlorinated drinking water in Taiwan. Environ. Res. 85, 77-82.

Jandl, R., Lindner, M., Vesterdahl, L., Bauwens, B., Baritz, R., Hagedorn, F., Johson, D.W., Minkkinen, K., Byrne, K.A., 2007. How strongly can forest management influence soil carbon sequestration. Geoderma 137, 253-268.

Joosten, H., 2009. The Global Peatland $\mathrm{CO}_{2}$ Picture: Peatland Status and Drainage Related Emissions in All Countries of the World. Wetlands International, Ide.

Keller, J.K., Bridgham, S.D., Chapin, C.T., Iversena, C.M., 2005. Limited effects of six years of fertilization on carbon mineralization dynamics in a Minnesota fen. Soil Biol. Biochem. 37, 1197-1204.

Kivimaki, S.K., Yli-petays, M., Tuittila, E.S., 2008. Carbon sink function of sedge and sphagnum patches in a restored cut-away peatland: increased functional diversity leads to higher production. J. Appl. Ecol. 45, 921-929.

Lofgren, S., Gustafsson, J.P., Bringmark, L., 2010. Decreasing DOC trends in soil solution along the hillslopes at two IM sites in southern Sweden - geochemical modeling of organic matter solubility during acidification recovery. Sci. Total Environ. 409, 201-210.

Lumsden, D.G., Stutter, M.I., Cooper, R.J., Manson, J.R., 2005. Model assessment of biogeochemical controls on dissolved organic carbon partitioning in an acid organic soil. Environ. Sci. Technol. 39, 8057-8063.

Mackay, A.W., Tallis, J.H., 1995. Summit-type blanket mire erosion in the forest of Bowland, Lancashire, UK: predisposing factors and implications for conservation. Biol. Conserv. 76, 31-44.

Marinier, M., Glatzel, S., Moore, T.R., 2004. The role of cotton-grass (Eriophorum vaginatum) in the exchange of $\mathrm{CO}_{2}$ and $\mathrm{CH}_{4}$ at two restored peatlands, eastern Canada. Ecosciences 11, 141-149.

Martikainen, P.J., Nykanen, H., Alm, J., Silvola, J., 1995. Change in fluxes of carbondioxide, methane and nitrous-oxide due to forest drainage of mire sites of different trophy. Plant Soil 168, 571-577.

Mitchell, R.J., Rose, R.J., Palmer, S.C.F., 2008. Restoration of Calluna vulgaris on grassdominated moorlands: the importance of disturbance, grazing and seeding Biol. Conserv. 141, 2100-2111.

Monteith, D.T., Stoddard, J.L., Evans, C.D., de Wit, H.A., Forsius, M., Hogasen, T., Wilander, A., Skjelkvale, B.L., Jeffries, D.S., Vuorenmaa, J., Keller, B., Kopacek, J., Vesely, J., 2007. Dissolved organic carbon trends resulting from changes in atmospheric deposition chemistry. Nature 450, 537-541.

Nilsson, M., Sagerfors, J., Buffam, I., Laudon, H., Eriksson, T., Grelle, A., Klemedtsson, L., Weslien, P., Lindroth, A., 2008. Contemporary carbon accumulation in a boreal oligotrophic minerogenic mire - a significant sink after accounting for all C-fluxes. Global Change Biol. 14, 2317-2332.

Olejnik, S., Algina, J., 2003. Generalized eta and omega squared statistics: measures of effect size for some common research designs. Psychol. Methods 8, 434-447.

Peacock, M., Evans, C.D., Fenner, N., Freeman, C., 2013. Natural revegetation of bog pools after peatland restoration involving ditch blocking - the influence of pool depth and implications for carbon cycling. Ecol. Eng. 57, 297-301.

Reed, M.S., Bonn, A., Slee, W., Beharry-Borg, N., Birch, J., Brown, I., Burt, T.P., Chapman, D., Chapman, P.J., Clay, G.D., Cornell, S.J., Fraser, E.D.G., Glass, J.H Holden, J., Hodsen, J.A., Hubacek, K., Irivine, B., Jin, N., Kirkby, M.J., Kunin, W.E. Moore, O., Moseley, D., Prell, C., Price, M.F., Quinn, C.H., Redpath, S., Reid, C. Stagl, S., Stringer, L.C., Termansen, M., Thorp, S., Towers, W., Worrall, F., 2009. The future of the uplands. Land Use Policy 26, S204-S216.

Santana, V.M., Marrs, R.H., 2014. Flammability properties of British heathland and moorland vegetation: models for predicting fire ignition. J. Environ. Manage. 139, 88-96.

Shackle, V.J., Freeman, C., Reynolds, B., 1999. Carbon supply and the regulation of enzyme activity in constructed wetlands. Soil Biol. Biochem. 32, 1935-1940.

Sharp, E.L., Parson, S.A., Jefferson, B., 2006. Coagulation of NOM: linking character to treatment. Water Sci. Technol. 53, 67-76.

Soini, P., Riutta, T., Yi-Petays, M., Vasander, H., 2010. Comparison of vegetation and $\mathrm{CO}_{2}$ dynamics between a restored cut-away peatland and a pristine fen: evaluation of the restoration success. Restor. Ecol. 18, 894-903.

Strack, M., Zuback, Y.A.C., 2013. Annual carbon balance of a peatland $10 \mathrm{yr}$ following restoration. Biogeosciences 10, 2885-2896.

Thurman, E.M., 1985. Organic Geochmistry of Natural Waters. Nijhoff/Junk, Dordrect.

Trinder, C.J., Artz, R.E., Johnson, D., 2008. Contribution of plant photosynthate to soil respiration and dissolved organic carbon in a naturally recolonising cutover peatland. Soil Biol. Biochem. 40, 1622-1628.

Turner, E.K., Worrall, F., Burt, T.P., 2013. The effect of drain-blocking on the dissolved organic (DOC) budget of an upland peat catchment in the UK. J. Hydrol. 479, 169-179. 
van der Werf, G.R., Randerson, J.T., Giglio, L., Collatz, G.J., Mu, M., Kasibhatla, P.S., Morton, D.C., DeFries, R.S., Jin, Y., van Leeuwen, T.T., 2010. Global fire emissions and the contribution of deforestation, savanna, forest, agricultural, and peat fires (1997-2009). Atmos. Chem. Phys. 10, 11707-11735.

Vasander, H., Tuittila, E.S., Lode, E., Lundin, L., llomets, M., Sallantaus, T., Heikkilä, R., Pitkänen, M.L., Laine, J., 2003. Status and restoration of peatlands in northern Europe. Wetland Ecol. Manag. 11, 51-63.

Volk, C., Wood, L., Johnson, B., Robinson, J., Zhu, H.W., Kaplan, L., 2002. Monitoring dissolved organic carbon in surface and drinking waters. J. Environ. Monit. 4,

$43-47$

Waddington, J.M., Toth, K., Bourbonniere, R., 2008. Dissolved organic carbon export from a cutover and restored peatland. Hydrol. Process. 22 (13), 2215-2224.

Wallage, Z.E., Holden, J., 2010. Spatial and temporal variability in the relationship between water colour and dissolved organic carbon in blanket peat pore waters.

Sci. Total Environ. 408 (24), 6235-6242.

Wallage, Z.E., Holden, J., McDonald, A.T., 2006. Drain blocking: an effective treatment for reducing dissolved organic carbon loss and water discolouration in a drained peatland. Sci. Total Environ. 367, 811-821.

Ward, S.E., Bardgett, R.D., McNamara, N.P., Adamson, J.K., Ostle, N.J., 2007. Longterm consequences of grazing and burning on northern peatland carbon dynamics. Ecosystems 10, 1069-1083.

Worrall, F., Burt, T.P., 1998. Decomposition of river water nitrate time series comparing the agricultural and urban signals. Sci. Total Environ. 210 (211),
274

Worrall, F., Burt, T.P., 2008. The effect of severe drought on the dissolved organic carbon (DOC) concentration and flux from British rivers. J. Hydrol. 361, 262-

Worrall, F., Burt, T.P., Adamson, J., 2006. Long-term changes in hydrological pathways in an upland peat catchment - recovery from severe drought? $\mathrm{J}$ Hydrol. 321, 5-20.

Worrall, F., Armstrong, A., Adamson, J.K., 2007a. The effects of burning and sheep$339,1-14$ grazing on water table depth and soil water quality in a upland peat. $\mathrm{J}$. Hydrol.

Worrall, F., Burt, T.P., Adamson, J.K., 2007b. Change in runoff initiation probability over a severe drought - implications for peat stability. J. Hydrol. 345 ,

16-26.

Worrall, F., Rowson, J.G., Evans, M.G., Pawson, R., Daniels, S., Bonn, A., 2011. Carbon fluxes from eroding peatlands - the carbon benefit of revegetation following wildfire. Earth Surf. Proc. Land. 36, 1487-1498.

Worrall, F., Rowson, J.G., Dixon, S.D., 2013. Effects of managed burning in comparison with vegetation cutting on dissolved organic carbon concentrations in peat soils. Hydrol. Process. 27, 3994-4003.

Yallop, A.R., Clutterbuck, B., 2009. Land management as a factor controlling dissolved organic carbon release from upland peat soils. Sci. Total Environ. 407, 3803-3813.

Yallop, A.R., White, S.M., Clutterbuck, B., 2008. Evidence for a mechanism driving recent observed trends in dissolved organic carbon release from upland peat soils. Aspects Appl. Biol. 85, 127-132. 